\title{
The Evolution of India-US Nuclear Relations: Conflicts and Co-operation From Past to Present Scenario
}

\author{
Jesmine Ahmed ${ }^{1}$ and Niranjan Mohapatra ${ }^{2}$ \\ ${ }^{1}$ Research Scholar, ${ }^{2}$ Assistant Professor, Department of Political Science, \\ Assam University, Diphu Campus, Karbi, Anglong, Diphu, Assam, India \\ E-Mail: jesmine.jes@gmail.com, niranjanmohapatra@ rediffmail.com
}

\begin{abstract}
India and the United States have long historical, diplomatic, strategic and cultural linkages. Since the genesis of the Indo-US engagement in the international politics, the issues relating to nuclear aspects have been a great source of divergence and convergence between the two countries. This relation is mostly revolve around the three major shifts; Pokhran-I (1974), Pokhran-II (1998) and Civilian Nuclear deal (2005).However, before the signing of civil nuclear deal, both the countries had many clashes for not signing India in NPT and CTBT. However, this paper focuses on the evolution of India -US nuclear relations since past and also discuss how US response to nuclear tests that India had conducted. It also concludes the agreements that led to the cordial relations between the two countries at present.

Keywords: Nuclear, Pokhran, NPT, CTBT, Indo-US Civil Nuclear Deal
\end{abstract}

\section{INTRODUCTION}

The India-US Relations date back to the time when India was still under the British rule. To understand the background of nuclear relation it is necessary to know the history of bilateral relations between the two countries. The relationship between the two countries had not always been as cordial as one finds them today, but for a long period of time, the bilateral relation remained calm and the main reason behind this is the "nuclear factor". In the beginning India received the assistance from US to exploit atom for peaceful purposes, but after India rejected to be the signatory of the Nuclear Non Proliferation Treaty and in 1974 when India conducted its first nuclear explosion USA get disappointed and their relation deteriorated.

The nuclear question arises during the Nehruvian period when USA provided assistance to India's nuclear programme. Though U.S-China-Pakistan nexus and the issue of non-proliferation disrupted the relations since 1970s, it showed a improvement during the Clinton Administration inspite of "India's decision to cross the nuclear Rubicon in May 1998".

However, towards the end of the 20th century and beginning of the 21 st century, US policy towards India got transformed into more friendly. After implementation of economic sanctions over India in 1998, US decided to enter into a strategic dialogue with India. The dialogue process paved the way for the enhanced understanding of national interests and constructive partnership between the countries that led to the ending of misunderstandings and thus boosted bilateral relation. This gradually arose the willingness from each country to work together in the field of strategic sector due to the mutual understanding of new priorities. In April, 2005 India had passed its weapons of mass destruction and their Delivery Systems (Prohibition of Unlawful Activities) Bill that shows its seriousness in moving complementarily with the US in order to facilitate the progress on the bill. After the Indo-US joint statement of 18 July 2005 a new era and an engagement between India and USA have started. It was for the first time US has come forward for fostering a better and closure relation with India after the cold war. However, this article seeks to analyze the evolution of nuclear relation of the two countries and its various reasons for cooperation and conflicts in this aspect since past. It also highlights various agreements concluded between them till August, 2018.

\section{DAWN OF INDIAN INDEPENDENCE: (COOPERATION AND CONFLICT)}

In 1947, when India emerged as an independent country, the nuclear age had already started. Our leaders then choose the path of non-alignment. They viewed that development of nuclear technology transformed the nature of global security. But due to the absence of universal nondiscriminatory disarmament that creates the arbitrary division between nuclear haves and have notes, India beliefs that it is the sovereign right of every nation to protect national interests. But at the same time it is also recognized that nuclear technology provides ample opportunity for economic development. This reflected in the enactment of the Atomic Energy Act of 1948. Thus, in the 1950s nuclear weapons testing took place under these grounds. Thus, India's decision not to sign the NPT was in keeping with the objectives of maintaining freedom of thought and action.

The tenure of Pandit Jawaharlal Nehru was marked by several significant decisions that shaped the behaviour of Indian nuclear relations in the later decades. It also reveals the dominant role of Indian political (Nehru) and scientific (Bhaba) leaders that influenced the Indian approach to nuclear questions.

In this era, Indian nuclear approach was a response to several factors at various levels: 
1. International environment, where India's independent position in cold war international system led to the great threat for Indian security and diplomatic interests by the American Policy that sought to control the atom in order to fulfill its strategic interests;

2. Regional environment, where China's nuclear activity created a potential challenge for Indian security in the context of Sino-Indian rivalry in Asia;

3. India's domestic environment where the nuclear question is associated with the importance of science in Indian development.

However, in 1948 India supported the Baruch Plan that created international agency to impose penalties on countries that violated international controls on nuclear weapons. But in 1954, Nehru expressed opposition to participate in an organization dominated by the great powers.

This period witnessed the establishment of the Indian Atomic Energy Commission (1948) and the initiation of atomic energy agreements with the UK, the USA, France, Canada in 1955. Though India rejected international atomic controls but accepted partial safeguards on foreign supplies. Between 1947-1964, India developed its civil and dual use nuclear programme. At this time Indian policy reflected a bend towards Soviet Union because US military aid to Pakistan in mid-50s and willingness of Soviet Union in economic and political development of India.

\section{THE NON-PROLIFERATION TREATY}

In 1960s due to Canadian help made India less dependence on USA, so a proposal was initiated at U.N by Ireland to stop the spread of nuclear power. The two nations cooperation led to the initiation of Nuclear NonProliferation Treaty, 1970. It is an international treaty whose objectives are to prevent the spread of nuclear weapons to promote cooperation in the peaceful uses of nuclear energy. It provided that the signatories would not provide any assistance to the non-nuclear weapon states in developing nuclear explosives. A total of 190 states have joined their treaty. India, Israel, Pakistan, South Sudan are some of the countries who have chosen to not sign the NPT.

\section{A. Reasons for India to Join NPT}

India wishes to be on a member of the UNSC (United Nations Security Council). As all the members of the UNSC are members of the NPT, it is speculated that this might be the reason for not including India as a permanent member. As it is the only comprehensive instrument for addressing global non-proliferation challenges, while preserving the right of NPT-member states to pursue civil nuclear energy.

\section{B. Reasons for India not to Join NPT}

In 1965, along with a small group of aligned countries , India had initiated the idea of an international non- proliferation agreement under which nuclear weapons states would agree to give up their arsenals and other countries would refrained from developing or acquiring such weapons. The major nuclear power countries did not give assurance for providing security when sought for support but desired to avoid them acquiring the nuclear technology. For this reason India did not sign NPT.

As they found that the countries who have nuclear weapons have no obligation to give them up while others are not allowed to have them. No fixed timelines have been mentioned. Apart from these, China has allegedly violated the treaty by proliferating it to Pakistan. Thus, it threatened national security. India did however sign the "no first use" treaty (which later changed to the no first use against nonnuclear weapon states) in 2010. For these reasons India decided to not sign NPT.

But later, the explosion of Pokhran I, first nuclear test of India in 1974 disturbed the USA. It was followed by harsh reaction from across the world. America continued to insist that India must signed the treaty while India considered it discriminatory. Thus, USA tried hard to disarmament South Asia in 1980s. Moreover, India shares $7500 \mathrm{~km}$ of borders with Pakistan and China. Both nations have nuclear weapons and have sought war with India. Thus it enhances India's security threat to sign NPT.

\section{COMPREHENSIVE TEST BAN TREATY}

The first test ban treaty in 1963 (signed by the US, Britain and the USSR), prohibited nuclear test explosions in the atmosphere, in outer space, or underwater - but continued to permit them underground. In fact, the three existing nuclear powers only agreed to such a treaty because they knew they could immediately switch over to underground tests without affecting their weapons programs. In 1974 a Threshold Test Ban Treaty (TTBT) was signed that set a size limit on underground test explosions. The CTBT, as its name suggests, proposes to go a step further in banning all underground tests regardless of size.

As weapons testing is a crucial part of the successful development and deployment of nuclear weapons the premise behind the CTBT is a ban on nuclear testing effectively that ends the ability of any country to develop and deploy new nuclear weapons. The CTBT would be most effective in stopping "threshold states" like India, Pakistan or Israel from being able to develop their nuclear option. But it is obviously of far less significance for the N5, who already have completed their testing and have their weapons in place. As such, the CTBT effectively takes the NPT a step further in practically consolidating the power and security of the nuclear states by ensuring that no country develops the ability to challenge this.

In such a manner, this treaty was adopted by the United Nations General Assembly in 1996 and obliges the states to ban all nuclear explosions in all environments for civilian 
and military purposes. The 1990s show the pressure building upon India to sign the Comprehensive Test Ban Treaty. India had been one of the earliest proponents of CTBT but later it rejected as this treaty promoted horizontal non proliferation like NPT. Moreover, it ended its test route to the development of nuclear explosive technology under laboratory conditions and endangered Indian security. India found it discriminatory as it led to Fissile Material Ban ( Fish Ban), that prohibit production of fissile material for the weapons outside international safeguards and require inspections to verify new productions. Apart from it US which has already conducted more than 2000 tests suddenly realizes that there is no need to test nuclear devices any more. As the treaty only ban nuclear explosive testing but not other activities related to nuclear weapons such as sub critical experiments. This treaty also provides a threat to national security.

In 1996 when the treaty was finally concluded and opened for signature, a consensus had emerged that India should not subscribe to it since it did not include any linkage with the issue of nuclear disarmament and neither did it meet India's security concerns. Although India has stood by its demand for a nuclear weapon free world; various principled, procedural, political, and security concerns have stood in the way of its support for the CTBT. India's main opposition drew from its emphasis on complete nuclear disarmament in a time bound manner. After the NPT extension in 1995, India felt that the only way to hold the N5 to a time bound elimination of nuclear weapons clause was through CTBT but 'time bound' were not incorporated into CTBT.

Moreover, it article XIV, the Entry Into Force (EIF) clause that India considered a violation of its right to voluntarily withhold participation in an international treaty. The treaty initially made ratification by states that were to be a part of CTBT's International Monitoring System (IMS) that mendatory for the treaty's EIF. Due to this reason India withdraw its participation from IMS. However, with the $20^{\text {th }}$ anniversary of CTBT's entry into signing, India and Pakistan two of only three Annex -II states that have not signed the treaty.

\section{POKHRAN- II TEST}

But after the disintegration of USSR in 1991, India increasing her cordial relation with US. But in late 1990s India test five nuclear tests at Pokhran that leads to implementation of economic sanctions against India. Thus, the post cold war scenario led to a great urgency on the part of USA to bring India and Pakistan into non-proliferation programme and tried to accept international inspection of their nuclear production facilities. The Pokhran II Test were a significant development in India's nuclear history. It was condemned by the US, P-5 countries and G-8 countries.USA imposed economic sanctions against India.
At this time, India had developed two intermediate-range missiles- Agni and Prithvi. There were suspicion in the mind of the US that the growing military strength by India would result in the destabilizing the military balance in South Asia. For this reason US pressurized India to abandon the further development of its missile programme but India went ahead and test fired the Agni, declaring it was only a technology demonstrator and that the system was not going to be deployed. However, India criticized the United States dual policy on proliferation of missile technology because the US remained soft when China acquired the missile technology and proliferate it to Pakistan, knowing it very well that there was every possibility that Pakistan would proliferate that to the third countries.

After the initial phase of condemnation US made attempts to come closer to India as it realized that the damage to nuclear regime done by the tests needed to repair quickly to preserve the residual legitimacy of nuclear regime. In the aftermath of Pokhran II, India announced a formal nuclear doctrine. It proclaimed a doctrine of 'minimum credible deterrence' Moreover, US and India agreed to enter a serious dialogue to reduce their differences. As a result nine rounds of talks were held in June 1998.

However, Pokhran II was a blessing in the context of IndoUS relations because in the short run, Pokhran II invoked strong reactions and sanctions from US to India but in the long run, US's philosophy about India has changed dramatically as within one month aftermath the Pokhran II, US agreed to engage India for the first time in high level security dialogue popularly known as Jaswant Singh Strobe Talbot Dialogue which started on June 12, 1998. During the course of these talks India was successful in convincing the US that it was the multiple-security threats from China and Pakistan which were the immediate causes for declaring itself as overt nuclear power.

\section{NEW PHASE OF NUCLEAR COOPERATION}

During the time of Bush administration USA started considering a strategic partnership with India. The Vajpayee Government participated in intense negotiations for four years and concluded the US-India Next Step in Strategic Partnership (NSSP) in 2004. It led to the expanded cooperation in civil nuclear technology.

\section{A. The Indo-US Nuclear Deal}

In 18 July, 2005, a joint statement was signed by president George Bush and the then Prime minister Manmohan Singh regarding "Global Partnership" that covers full civilian nuclear cooperation .India agreed to continue its unilateral nuclear test moratorium and work with USA to conclude a Fissile Material Cut-off Treaty (FMCT).Both countries secures its nuclear materials and technology through comprehensive export control legislation and through adherence to Missile Technology Control Regime (MTRC), and NSG guidelines. 
It was a landmarked agreement on India-US nuclear cooperation as USA agreed to amend the laws to end of three decades embargo imposed after the Indian Nuclear explosions in 1974. By this agreement India acquire same advantage as other leading countries with advanced nuclear technology, like United States.

India rejected Hyde Act (U.S -India Peaceful Atomic Energy Cooperation Act of 2006) on the grounds of its violation of India's sovereign right to conduct nuclear test.Hyde act envisages India to jointly participate with the U.S. in a programme involving the U.S National Nuclear Security Administration to further nuclear non proliferation goals. This goes beyond the IAEA (International Atomic Energy Agency) norms and has been unilaterally introduced apparently without the knowledge of the Indian Government .Moreover, India is required to annually report to the congress whether India is actively participating in US. It also prohibits any future cooperation between India and Iran. These stipulations in the act and others pertaining to the Proliferation Security Initiative( PSI), the Wassenaar Arrangement, and the Australia Group etc. are totally outside the scope of the July $18^{\text {th }}$ Agreement and they constitute intrusion into India's independent decision making and policy Matters.

India has always been subjected to the United States sanctions, pressures and denial of high technology because of its nuclear programme and decision not to sign the NPT. As India has developed most of its nuclear programme indigenously therefore it opposed the International Atomic Energy Agency (IAEA) guideline on nuclear safeguards, control and inspections systems in its nuclear plants.

\section{B. 123 Agreements}

The Bush administration showed an interest to become a strategic partner of India. The framework for this agreement was a July 18, 2005, joint statement by then Indian Prime Minister Manmohan Singh and then U.S. President George W. Bush, under which India agreed to separate its civil and military nuclear facilities and to place all its civil nuclear facilities under International Atomic Energy Agency (IAEA) safeguards and, in exchange, the United States agreed to work toward full civil nuclear cooperation with India. The 123 agreement is meant to provide India clean energy, a major source of sustained economic growth and also to curb the emission of gases responsible for global warming. Under this, India has put two thirds of its existing reactors and $65 \%$ of its generating power under permanent safeguards with international verification and in return United States supply nuclear fuel and technology to India. The nuclear deal grants India the facility of reprocessing the nuclear fuel acquired from the external sources. However, it was revealed by the Nuclear Power Corporation of India it will assist India in meeting its aspiration of addition of 25,000 MW of nuclear power facility in the course of imports of nuclear reactors and fuel by 2020 .
The 123 agreement gives the operational origin to the IndoUS civil nuclear cooperation and lays the groundwork for the ultimate law that would permit US companies to originate nuclear traffic with India. The agreement provides that the US would cut off the supply if India tests nuclear weapon. However, In the article 2 paragraph 4 of the 123 agreement both the countries insists that the "purpose of this agreement is to provide for peaceful nuclear cooperation and not to affect the unsafeguarded nuclear activities of either Party". The controversial section123(a)(4) US atomic energy act gives the US government the right to ask for return of any nuclear material and equipment transferred under this deal if India conducts a nuclear test or terminates the IAEA agreements.

This U.S.-India deal passed through several complex stages such as amendment of U.S. domestic law, especially the Atomic Energy Act of 1954,a civil-military nuclear Separation Plan in India, an India-IAEA safeguards agreement and the grant of an exemption for India by the Nuclear Suppliers Group, an export-control union had formed mainly in response to India's first nuclear test in 1974. In its final shape, the deal places under permanent safeguards and on February 2, 2009, India signed an Indiaspecific safeguards agreement with the IAEA. After India brought this agreement into force, inspections were conducted in a phased manner on the 35 civilian nuclear installations that India has identified in its Separation Plan. Thus, the deal is seen as a watershed in U.S.-India relations and introduces a new aspect to international nonproliferation efforts.

The US Nuclear Non-proliferation Act aims to prevent proliferation by denying access to nuclear technology and nuclear materials for states that have refused to sign the NPT. To strengthen controls on export of the nuclear technology and materials to such countries the Nuclear Suppliers Group (NSG) was established in 1970s by US. On August 1, 2008, the IAEA approved the safeguards agreement with India, after which the United states approached the NSG to grant a waiver to India to commence civilian nuclear trade. The NSG decided to give waiver to India on September 6, 2008 permitting it to access civilian nuclear technology and fuel from other countries. India also pledged to carry on its voluntary suspension on nuclear testing, but has not assured to bring an end in producing plutonium. The implementation of this waver made India the only known country with nuclear weapons which is not a party to the NPT but still allowed to carry out nuclear commerce with the rest of the world. Later the deal became law on October, 2008 and named as US-India Nuclear Cooperation Approval and Non-Proliferation Enhancement Act.

\section{Features of the Agreement}

1. The Agreement is "between two States possessing advanced nuclear technology, both parties having the same benefits and advantages". 
2. The purpose of the agreement is to enable full civil nuclear energy cooperation between India and the United States. The Agreement provides for full civil nuclear energy cooperation covering nuclear reactors and aspects of the associated nuclear fuel cycle including enrichment and reprocessing.

3. The Agreement contains a full reflection of the March 2, 2006 supply assurances, and the provision for corrective measures. The Agreement provides for the development of a strategic reserve of nuclear fuel to guard against any disruption of supply over the lifetime of India's reactors.

4. The Agreement provides for nuclear trade, transfer of nuclear material, equipment, components, and related technologies and for cooperation in nuclear fuel cycle activities.

5. The Agreement provides for the application of IAEA safeguards to transferred material and equipment.

6. The Agreement grants prior consent to reprocess nuclear material, transfer nuclear material and its products. To bring this into effect, India will establish a national reprocessing facility to reprocess IAEA safeguarded nuclear material and the parties will agree on arrangements and procedures within one year.

\section{Reaction against the Nuclear Deal in India}

The deal received worldwide opposition from various groups including non-proliferation activists, anti-nuclear organizations, and others. However, the countries like United Kingdom, France, Japan, Russia, and Germany welcomed the deal. After a historic civil nuclear cooperation agreement different views have been expressed by Indian politicians.

The critics revealed that the deal will allow India to deflect its domestic uranium reserves towards its nuclear programme. Yashwant Sinha one of the political leaders viewed that the agreement reflects the rules of the Hyde act. The former Directors of the Bhabha Atomic Research Centre held that this accord is totally against national interest.. Some favoured the agreement and accepting the necessity for nuclear energy in the years ahead, as it would make India's energy resources much better. Others argued that the separation plan is a troublesome task.

The then main opposition party BJP and the left ally CPI (M) of the government were against the agreement. They claim that the terms of the deal jeopardize India's nuclear weapons programme and therefore the country's strategic autonomy. In general terms, the BJP has considered the deal to compromise: national security issues, autonomy of India's decision-making processes, the autonomy and independence of our nuclear programmes. Moreover, the 123 Agreement, indirectly endorsing the Hyde Act of 2006, the BJP criticized the most.. The leftists, which were part of the ruling coalition in India, registered a huge criticism against the government for not taking them into consideration before signing the nuclear deal with the US. They vehemently criticized the America's recognition of India as a responsible state with sophisticated nuclear technology that obtain the same benefits as other such states falls short of admitting it into the nuclear club.

\section{E. Benefits to India}

India has been the chief gainer of the agreement. It is a remarkable triumph for India to build up its nuclear programme. It will assist India in covering its growing energy requirements. The deal puts an ending to India's decades old nuclear segregation and technology denial regimes as India sought international nuclear collaboration, even while maintaining a nuclear weapons programme, by approving to partial safeguards on nuclear imports. Due to historic agreement, India became the only country of the world with the de-facto nuclear status even without being signatory to the non proliferation treaty. Without signing the NPT and CTBT, India would able to get strategic assistance from NPT members. Another major benefit the nuclear deal provides to India is that it will get fuel for its nuclear reactors not only from the US but from other suppliers as well.

This agreement was an indication of a more intensified engagement in the wide ranging areas that have been identified for our bilateral co-operation including high technology, agriculture, science and technology, space, defence, and global issues of common concern related to the environment, climate change etc. It also helped to address the problem of energy deficit that has emerged as one of the primary constraints on accelerating India's growth rate.

\section{F. Benefits to US}

Like India, the deal is of ample importance for the US as well. Because it provides huge benefits to it ranging from economic to strategic issues. Some of the notable benefits are:

The agreement has a great potential to boost economic fortunes of US. It will generate a business of \$40 worldwide in next fifteen years as India plans to build about 24 reactors in next 15 years. It will also open new markets for American firms and will generate employment opportunities for the Americans. Moreover, U.S. benefits enormously with India as a chief military power. $40 \%$ of worlds' oil and commerce passes through the Indian Ocean sea lanes. Indian collaboration will be supportive in keeping the sealanes free. Further, the deal with India will help US in balancing the rising power of China. The Bush administration has considered China as 'future military adversary' and an important 'strategic issue' facing US. The deal is an advantage for the US nuclear sector as it will revive undeveloped American nuclear industry which was gradually losing markets in the world and will make it globally more competitive. The aerospace and defence sectors will also obtain huge benefits. Moreover another important benefit which the US achieved was that the civil 
nuclear cooperation brought India much closer to the NPT regime.

\section{G. India and NSG}

NSG (Nuclear Suppliers Group) was signed among 48 nuclear supplying countries to ensure trade for peaceful purposes and non proliferation on response to India's nuclear tests in 1974 at Pokhran. It laid down the norms for nuclear technology and prevents proliferation by banning the sale of some materials used for weapon making.

\section{H. Reasons for seeking a member of NSG}

1. If India becomes a member it will have better international market for exports and imports of nuclear related materials. India is keen to become a member of NSG and other export control regimes as it seeks to significantly expand its nuclear power generation.

2. All nuclear based programmes of India is run by indigenous technologies. By becoming a member Of NSG India can access to sophisticated foreign technologies.

Moreover, for building nuclear reactors and for providing more energy we need nuclear materials. By becoming a member of NSG we can better access nuclear materials and thus can fulfill the dream of becoming a player in international arena in this regard. Thus membership of NSG will provide greater certainty and legal foundation to India's nuclear regime.

However, India has been trying to get into NSG since 2008. India is supported by USA, Switzerland, Mexico for its membership of NSG. But it is opposed by China, New Zealand, South Africa and Pakistan as India is a nonsignatory of NPT, CTBT and therefore India should not be given a NSG partnership.

In 2008, the NSG exempted India from the requirement adopted by the NSG in 1992 banning nuclear cooperation with any state that had not accepted IAEA comprehensive safeguards. That allowed India to engage in nuclear trade with NSG members. India got its exemption on the basis of certain nonproliferation commitments to which it agreed under the India-US Civilian Nuclear Agreement. These include:

Separating its civilian and military nuclear facilities in a phased manner; placing civil nuclear facilities under IAEA safeguards; signing and adhering to the IAEA's Additional Protocol; working with the US for the conclusion of the Fissile Material Cut-off Treaty (FMCT); refraining from the transfer of enrichment and reprocessing technology to states that do not have them and supporting international efforts to limit their spread; introducing comprehensive export control legislation to secure nuclear material; and adhering to the Missile Technology Control Regime (MTCR) and NSG guidelines.
Moreover, India had announced setting up of a Global Centre for Nuclear Energy Partnership (GCNEP) during the NSS 2010 held in Washington D.C. The uniqueness of GCNEP rests on its holistic vision of nuclear energy through its five schools on advanced nuclear energy systems, nuclear security, radiological safety, nuclear material characterization, and applications of radioisotopes and radiation technologies, each specializing in an area that promotes an overarching vision of safe, secure and sustainable nuclear energy for global good.

\section{INDIA AND IAEA (THE INTERNATIONAL ATOMIC ENERGY AGENCY)}

India has consistently supported the IAEA's central role in facilitating national efforts and fostering effective international cooperation to further strengthen nuclear security. Indian experts have been participating in various bodies established by the IAEA to draft and review documents related to nuclear security. India has supported the fifth revision of the document on nuclear security recommendations and included a reference to it in its nuclear cooperation agreements where applicable. India is a participant in the IAEA's Incident \& Trafficking Database (ITDB) and has voluntarily adopted the provisions of the IAEA Code of Conduct on the Safety and Security of Radioactive Sources. IAEA has carried out review of Indian Pressurized Heavy Water Reactors under the "Operational Safety Review Teams" (OSART) mission.

Moreover, IAEA has conducted the "Integrated Regulatory Review Service" (IRRS) review of India's regulatory agency, the AERB. India proposed a workshop on IAEA's International Physical Protection Advisory Service (IPPAS) with the Agency experts during the year 2016. India participated at the Ministerial level in the International Conference on Nuclear Security organized by the IAEA in 2013 and also participated at the appropriate level in 2016 as well. India also participated in the December 2012 Fukushima Ministerial Conference on Nuclear Safety. India contributed \$ 1 million to IAEA's Nuclear Security Fund in 2013 and also contributes a similar amount in 2016 as well. In addition, India made a voluntary contribution of US\$ 100,000 in 2015 for the modernization of IAEA's nuclear applications laboratories in Seibersdorf, Austria under the $\mathrm{ReNuAL}$ project.

On 2015, January addressing a press conference with Narendra Modi, Obama said that the two countries were "moving forwards full implementation" of the Civil Nuclear Energy Deal. On 27 March, 2015, The International Atomic Energy Agency (IAEA) urged India to further tighten its nuclear safety regulations by assuring the legal independence of its atomic inspections. India, which has tested nuclear weapons but is a non-signatory of the Nuclear non-proliferation treaty( NPT), announced a major deal in January 2015 and decided to open nuclear power sector to US investment. It was the outcome of Prime Minister's visit to USA in 2014 to tighter checks of India's civilian nuclear 
programme by the IAEA. After 12 day of Indian P.M, the agency recommended that India and its Atomic Energy Regulatory Board (AERB) initiate further action to assure safety in its nuclear industry.

The chairman of the AERB, S.S. Bajaj said, "The government should embed the AERB's regulatory independence in law, separated from other entities having responsibilities or interests that could unduly influence its decision making. The AERB should consider increasing the frequency of routine on-site inspections at NPPs to allow for additional independent verification and more effective regulatory oversight," it added, referring to nuclear power plants (NPP).The nuclear "breakthrough understanding" between U.S. President Barack Obama and Modi seeks to allay U.S. concerns about industry liability and unlock billions of dollars in investments into Indian power projects."

\section{2016 NUCLEAR SECURITY SUMMIT}

The 2016 Nuclear Security Summit was a summit held in Washington, D.C., United States on March 31 and April 1, 2016. It was the fourth edition of the conference, succeeding the 2014 Nuclear Security Summit. From South Asia, India and Singapore attending the summit. In concern with the security requirements as perceived by India, the nuclear security architecture in the country has been strengthened and India has also participated in strengthening security architecture at the global level.

In 2016, US president thanked the prime minister for his active contribution in 2016 Nuclear Security Summit in Washington and welcome his offer to host a Summit on Countering Weapons of Mass Destruction Terrorism in 2018. The US president also welcomes India's application to join the Nuclear Supplies Group (NSG) and reaffirmed that India is ready for membership. The Nuclear Power Corporation of India and Westinghouse agree to conclude contractual arrangements for 6 reactors in June 2017.

\section{CONCLUSION}

Thus, it is evident that India US nuclear relation has been passed through various stages of cooperation and conflict and it determined as one of the important factors in maintaining their bilateral relations since past. Though there arose many criticisms from Indian politicians and other countries the US-India breakthrough after the end of the cold war is historic in the sense that it has improved India's global stand. The nuclear deal along with other agreements provides an ideal opportunity to emerge as an economic, military and political power centre. The Civil Nuclear deal ease India's security dilemma. India needs to negotiate with the US and NSG to ensure its national interests and to ensure that even of any alternation in the strategic environment it will need to secure its sovereignty and integrity. Thus, the bilateral civil nuclear cooperation is a milestone as it all about civilian nuclear energy cooperation so that to meet the growing India's energy requirements. Moreover, through this deal, US is exclusively attempting to strengthen India into its coalition alliance to encourage its strategic benefits as United States sought the nuclear agreement with India to control China and to establish itself in the enormous Indian nuclear market. The nuclear deal also serves the broad economic objectives of both the nations. In contemporary times, both the nations are treading in the path of mutual cooperation and strategic relation. Thus, the nuclear agreements concluded between the countries also influence the mutual relation of both. It boost the partnership of them as it benefitted much . Further it leads to the end of mistrust and a positive environment for future collaboration.

\section{REFERENCES}

[1] Alagappa, Muthiah (ed.). (1998). Asian SecurityPractice. Stanford; Stanford University Press.

[2] Alam, Mohammed B. (1995). Essays on Nuclear Proliferation. New Delhi: Vikas Publishing House.

[3] Alam, Mohammed B. (1988). India's Nuclear Policy. New Delhi: Mittal Publications.

[4] Albright, David. (1998). India and Pakistan's Fissile Material and Nuclear Weapons Inventory. Washington, DC: Institute of Science and International Security.

[5] Arnett, Eric (ed.). (1997). Military Capacityand the Risks of War. Oxford: Oxford University Press.

[6] Babbage, Ross and SandyGordon (eds.). (1992). India's Strategic Future: Regional State or Global Power? New York: St. Martin's Press.

[7] Bailey, Kathleen C. (ed.). (1994). Weapons of Mass Destruction: Cost Versus Benefits. New Delhi; Manohar Publishers.

[8] Dunn, Lewis A. (1982. Controlling the Bomb: Nuclear Proliferation in the 1980s. New Haven: Yale University Press.

[9] Freedman, Lawrence. 1981). The Evolution of Nuclear Strategy. New York: St. Martin's Press. Gordon, Sandy. 1995. India's Rise to Power. New York; St. Martin's Press.

[10] Sareen, S. (2016). India's Nuclear Doctrine May Not Be Revised, but Needs to Be More Dynamic. Free Press Journal, November 22. Retrieved from http://www.freepressjournal.in/analysis/indiasnuclear-doctrine-may-not-be-revised-but-needs-to-be-moredynamic/975734

[11] Scroll Staff. (2016). India Should Not Bind Itself to a 'No-First-Use Nuclear Policy', Says Manohar Parrikar. Scroll. In, November 10. Retrieved from https://scroll.in/latest/821251/india-should-not-binditself-to-a-no-first-use-nuclear-policy-says-manohar-parrikar

[12] Shukla, A. (2016). "The Non-Debate over Nuclear "No First Use."” Business Standard, November 21. Retrieved from http://www. business-standard.com/article/opinion/ajai-shukla-the-non-debateover-nuclear-no-first-use-116112101355_1.html.

[13] Subrahmanyam, K. (1985). Building Trust On The Bomb: What India And Pakistan Can Do. The Times of India, July 30. Retrieved from https://search.proquest.com/docview/614218804/abstract/CF57CF4C 08E44FE5PQ/5

[14] Vajpayee, A. B. (1998a). Paper Laid on the Table of the House on Evolution of India's Nuclear Policy. New Delhi, May 27. Retrieved from http://parliamentofindia.nic.in/ls/lsdeb/ls12/ses2/0527059801. htm. 